\title{
Cocoa as an Early form of Money in the Economic Sense: Satisfying Store of Value, Unit of Account and Medium of Exchange Requirements
}

https://doi.org/10.21272/sec.5(4).90-97.2021

Paul F. Gentle, ORCID ID: https://orcid.org/0000-0002-0317-0166

PhD, Visiting Professor of Economics and Business, NCC British Higher Education, GZIT Guangzhou, China

\begin{abstract}
This article examines the special case of cocoa in different parts of Mesoamerica, as it was used for an additional purpose, besides providing for nutritional needs of people, as well as for religious and other ceremonies. When confidence in a system of currency with coins is present, this more conventional form of money takes precedence. A respected economic form of currency which may include paper and coins or accounts thereof, has all three elements of money: a medium of exchange, a store of value and as a unit of account. In this article, the concept of value includes subjective value, what people have in terms of pleasure and displeasure in regard to owning and seeing a particular object. This article shows that cocoa satisfied the three requirements for serving as a form of money, during some time periods and in some areas of Mesoamerica. It has been found that cocoa met the three criteria necessary for them to be a type of money, in history in different countries. Some examples include certain past time periods in parts of Mesoamerica (part of present-day Latin America). However, cocoa was later found to not work as well, compared to some other specific forms of money. Understanding how different forms of money appear and then are replaced by other forms of money is important in the quest to understand what exactly money is. Monetary theory concepts concerning Gresham's Law and the Quantity Theory of Money are discussed regarding using cocoa as money.
\end{abstract}

Keywords: defining money, cocoa, Mesoamerica.

JEL Classification: N00, N10.

Cite as: Paul F. Gentle (2021). Cocoa as an Early form of Money in the Economic Sense: Satisfying Store of Value, Unit of Account and Medium of Exchange Requirements. SocioEconomic Challenges, 5(4), 90-97. https://doi.org/10.21272/sec.5(4).90-97.2021.
Received: $\quad 17.08 .2021$
Accepted: 17.10 .2021
Published: 30.12 .2021

Copyright: (C) 2021 by the author. Licensee Sumy State University, Ukraine. This article is an open access article distributed under the terms and conditions of the Creative Commons Attribution (CC BY) license (https://creativecommons.org/licenses/by/4.0/).

\section{Introduction}

In this article, an answer is sought after to determine if cocoa served well as a form of money in various countries and various time periods. Therefore, what needs to be answered is if cocoa fulfilled the three necessary requirements for an item to serve as money. As Mishkin (2006) points out, "money has been different things at different times; however, it has always been important to people and to the economy."

Intriguingly, money can be referred to "as anything that is generally accepted in payment for goods or services or in the repayment of debts" (Mishkin, 2006). Sometimes, money is currency with coins, and this is what lay people first think of when they hear the word "money". Moreover, economists add in deposit accounts and financial instruments, such as bonds (Mishkin, 2006). Baron (2018), an anthropologist who has done much work in the area of economic anthropology, including how cocoa served as money for a time period in 
Mesoamerica. (Figure1 indicates the location of Mesoamerica.) Baron (2018) agrees with Mishkin's (2006) list for the three requirements for something to be known as money. The three requirements that Mishkin (2006) lists are that for an item to be considered money, the item must be a medium of exchange, be a source of value and have a unit of account. Furthermore, both Mishkin (2006) and Baron (2018) agree that money is used as a means of payment for debts. However, Baron (2018) states that as a fourth the traits of money. Mishkin (2006) and Barron (2018) have no disagreement on this. Pearce (1986) and Baron (2018) state that sometimes, there has been the use of commodity money. With a commodity money system, the value of the commodity has value, determined by a society's consensus.

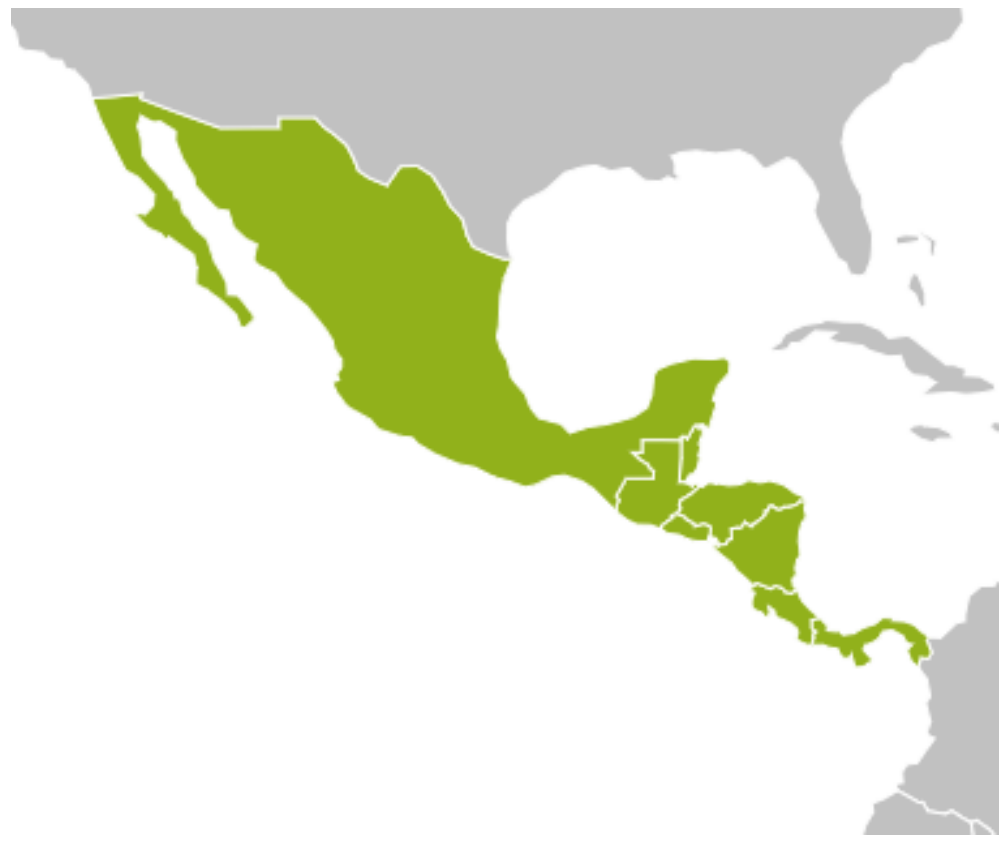

Figure 1. Mesoamerica

Source: mesoamerica@nepcon.org.

Pearce (1986) and Mishkin (2006) concur in the view that in order for something to be money, three requirements must be met. These three requirements are being a store of value, having a unit of account and being a medium of exchange. The next section will be a literature Review, concerning what is necessary for something to be money, with some illustrations. This is followed by an analysis section, especially about cocoa as money and then a section discussing the concept of value, in regard to money. Finally, a summary and conclusion section complete this article. On the necessary value trait, Baron (2018) points that value can come from the intrinsic value of whatever item serves as money and value can also come from "state enforced consent" Crucially, these two sources of value are not mutually exclusive. Furthermore, the degree to which a type of money can have its value examined as the intrinsic value or state enforced consent value, can very over time and between cultures.

Cocoa also had important uses in other ways besides as money. For example, "The brewing and sharing of alcohol among elites may have played a role in creating incipient social hierarchies in these small communities" (Henderson et al., 2006; Baron, 2018). The flavorful and stimulating properties of the fermented cocoa beans were eventually discovered. Therefore, and a frothy, sudsy nonalcoholic beverage was invented by further processing them through drying, toasting, grinding, and mixing them in water. So, before the drink was consumed more widespread, "the drink served as a new marker of social status - supplanting the more ancient alcoholic beverage, but not replacing it" (Henderson et al., 2006; Baron, 2018). Baron (2018) states that coca drink was common became standard fare among Mesoamerica's elites, for ceremonial occasions such as weddings, and as a food for gods. Using cocoa for these purposes continued on, even after cocoa was 
monetized. "Contact-era sources indicate that the value of cocoa beans in exchange was tied to their desirability in the production of this chocolate drink". (Baron, 2018).

Religious and ceremonial uses of cocoa have been described by many scholars (McNeil, 2006). Cocoa was so important to pre-Columbia Mesoamerica that there is much in their religion, concerning it (Baron, 2018). Cocoa served as a type of currency among the Contact and Colonial period Maya. Also, the merchant god Ek Chuaj was one of the deities associated with the plant (Pugh, 2006).

\section{Literature Review Concerning Other Items}

There are unique situations when something less familiar, to most contemporary people, takes on traits of money, most often in an environment and time when currency with coins are not present. For instance, cigarettes were used as a type of money in prisoner of war camps in Germany during World War II (Radford, 1945). Earlier, Native American wampum served as a means of recording treaties, histories, and sometimes messages within tribes and between tribes and other non-monetary uses, in some areas of what is now the Eastern part of North America. However, once European settlers came to Eastern North America, the wampum started also being used as valued money, becoming a medium of exchange, in that area. Black beads of wampum were more valuable than white beads and so we can see an example of money having a unit of account. In part of Eastern North America, once Western European settlers came to the area until sometime in the eighteenth century, wampum was recognized as a medium of exchange, had units of account (black beads and white beads) and some store of value (Peña, 2001, 2003; Gentle, 2016). Similarly, different quantities of warehouse receipts served as money during part of the colonial period in Virginia. Moreover, receipts for that tobacco during part of the time era of colonial Virginia, did satisfy all three requirements for something being money (Gentle, 2018). The store of value requirement would be at least somewhat satisfied by cigarettes in prisoner of war camps in Germany (Radford, 1945). A cigarette can stay fresh for probably a shorter time than would tobacco aged in a warehouse or very large barrel. Hence, tobacco stored in a warehouse or barrel, tended to hold value longer. At one time, beaver fur pelts served as money in parts North America. (Gentle, 2020; Gentle, 2018). Rice served as commodity money in certain areas of the world during some historical times (Gentle, 2021a).

An accepted currency with coin system would satisfy the three traits requirement well. Precious metals such as coins of gold and silver or notes, representing those precious metals, can also satisfy the necessary traits for something being money. The absence of such money causes some alternatives to be used and that was the case for different economies at one time. This article examines several cases, where cocoa was used as money, at different times in the areas known today as part of Latin America.

\section{Analysis of Cases regarding Cocoa}

The long history of cocoa currency considers different geographical areas such as Mesoamerica (part of presentday Latin America). Commodities other than gold and silver have been used for money. Cocoa was one of those non-metallic commodities used for money in certain places and at particular time periods (Baron, 2018; Learn, 2018; Nield, 2018; Palace, 2018). At this point in this article, some examples are considered. These examples are of all the times and places in history where cocoa may have been used as money not an exhaustive list. The use of cocoa as money was present even before the Spanish had contact with Mesoamerica. Within this vast area, Aztecs, Mayan and other tribes lived. (For more information about these specific other tribes, see Baron, 2018, a seminal article). Some of this section refers to Aztecs or Mayas. However, there is much overlap and some similarities that not always the same exact ways, in how these two tribes and even other tribes used coca as a form of money, at times both before and after contact with Spaniards. Cocoa was used as money among the Aztecs in the early colonial times. Examples include that at one time, 100 cocoa beans payment is what was paid for the daily wage of a porter in the area of today's Central Mexico. A small rabbit cost 30 cocoa beans and a fish wrapped in maize husks was 3 cocoa beans. Also, a large tomato was worth 1 cocoa bean. These and other examples are provided by Aguilar-Moreno (2006). Tribute between groups in Mesoamerica, both before the Spanish conquest and afterwards, involved the payment of cocoa (Fowler, 2006). The Aztecs used a currency based on cocoa (Kaufman and Justerson, 2006). And in the colonial period, after the Spanish came, 
Aztecs continued using cocoa as form of money. Cocoa could be used to purchase a number of commodities and, payment for services. It could also be used for manumission from slavery (Kaufman and Justerson, 2006; Reents-Budet, 2006).

In Mesoamerica, "the good cocoa and circulated as money the inferior broken cocoa unsuitable for food or seed, giving history another example of currency debasement and Gresham's law" (Beanz, 2011; Cocoa money 2011). At least among the Aztecs, there were cases of counterfeiting good cocoa with lesser grade cocoa that had been disguised in some way (Corrascso. 2008; Baron, 2018). Cocoa beans "can only be stored of up to a year before they start to suffer from mold and disintegration " (Baron, 2018). Although the "perishability of cocoa may have been prevented inflation," it may have also become problematic in times of a shortage of cocoa (Baron, 2018).

The Mayan culture used cocoa beans as a form of money. With the Spanish colonization, this continued. In fact, this continued $\mathrm{n}$ even to the mid-1800s (McAnany et al, 2006; McNeil, 2006; Pugh, 2006). Furthermore, both the Nicaro and Greater Nicoyans used coca as a form of money. Interestingly at times, the crop was put under restricted control by the aboriginal populations. Also, the units of the cocoa changed in their appellation after the Spanish arrived to a term used by the Spanish (Steinbrenner, 2006). Baron (2018) maintains anthropologists understand that the social relationships of the people using cocoa as money, concerns the production, circulation and consumption of cocoa. Gentle, the author of this publication you are now reading, states that perhaps anthropology does examine relationships in more detail compared to economics sometimes. The conclusion from this could be that more collaboration between anthropologists and economists and other types of scientists could be fruitful in advancing the knowledge of humanity about cocoa beans as money or about many other topics.

Both cotton textiles and cocoa were eventually used as money in Mesoamerica. Yet both were originally used to indicate status within the aboriginal societies of Mesoamerica. As both items became more prevalent, they were eventually circulated as money (Baron, 2018). The monetization "crossed ethnic and linguistic boundaries" and were used for buying and selling in the marketplaces (Baron, 2018). These items were used to pay for labor, tribute and were used in gambling. Indeed, when the Spanish first came in the early 1500s, they adopted these same cocoa and textile currencies (Baron, 2018). One helpful phenomenon was apparent with these items as currencies. That was that the governing regimes-imposed standardization of the required characteristics of the woven textiles and cocoa beans that were used as money. Furthermore, cotton was more widespread in its cultivation than cocoa was (Baron, 2018). Importantly, the cocoa tree is quite picky and can "only be grown intensively in deep alluvial soils of river valleys where subsoil is consistently moist. It also requires high temperatures, over 90 percent humidity, heavy rainfall, and protection from sun and wind" (Millon, 1955; Baron, 2018). Cocoa could serve the monetary functions of a medium of exchange and store of value better than some other commodities. The unit of account requirement is also met (Beanz, 2011; Cocoa money, 2011).

The research on cocoa in this article shows that cocoa did fulfill the three requirements necessary to be money, during certain time periods in different parts of the World. Rothbard, (2002), maintains that when other forms of money are not available or do not inspire enough confidence, then people may have confidence in certain commodities to serve as a type of money. For instance, during part of the history of colonial Virginia, warehouse receipts for tobacco were used between people as a form of money, since receipts were backed up by 100 percent tobacco (Brock, 1975; Rothbard, 2002, Gentle, 2018). An example of commodity money would be rice in colonial South Carolina (Rothbard, 2002). An examination of all commodity money may be intriguing. Yet, during part of colonial times, in part of Northeast North America, beaver fur pelts were important in colonial times in some part of present-day United States but in part of colonial times, possibly used to some degree as money. In beaver fur pelts were used on a formalized basis. The beaver pelts were a store of value. These pelts were used as a medium of exchange, especially in interactions between the colonists and aborigines in some parts of North America (Leduc, 2000; Horizon, 2001; Gittings et al., 2006; Gentle, 2020). A prime male beaver pelt was the unit of account, that other items were compared to. Commodities such as tobacco and beaver fur pelts fulfill a dual need. Beaver fur pelts were used and still are to some extent, as part of apparel. The tobacco is useful in tobacco products and as the basis for warehouse receipts, used as money in the Virginia 
colony for a time (Gentle, 2018). Gentle (2021b) explains how stone money was used at one time in the island group of Yap. Wampum was used to record treaties to express words for personal activities, such as condolences for the passing of a person and other matters. Later, once the European colonists came to North America, wampum was sometimes used as a form of money (Gentle, 2016).

\section{Subjective Value and the Quantity Theory of Money}

The subjective value would be determined by the degree of an individual's pleasure or displeasure in looking at and owning an item (Menger, 1871; Stigler, 1950; Mankiw, 2015). The other type of value is intrinsic value, what cocoa had $\backslash$, due to its value as food and an ingredient for a beverage. In Gentle (2018) it was shown that warehouse receipts for tobacco in colonial Virginia can be an example of money, fitting the Quantity Theory of Money, where MV = PQ. The Quantity Theory of Money's four factors can be as shown this way: M denotes the money supply; V denotes the Velocity of money; P denotes the cocoa Price level in terms of cocoa beans and Q stands for Quantity of goods and services. Also, in this paper, M could be cocoa beans. More of M would result in P increasing, if V and Q were constant. Different cocoa based monetary systems perhaps may have had some similar relationships. The exact unit measurements could vary for the different economies, built on a cocoa based monetary system.

As Mishkin (2006) has stated, one of the required traits for something to be considered money, is being a store of value. This paper has mentioned several items that served as money. One common trait for these type monies is being a store of value. Yet some types of money will hold their value longer than other types. Interestingly, a cigarette may decompose in as little time as a few months. A cigarette meets the store of value requirement for money. However, it may not last as long as tobacco in a warehouse or in a large barrel. So stored tobacco is a whole different product compared to cigarettes. Furthermore, stored tobacco holds its value longer than cigarettes do (Nettles, 1964; Gentle, 2018). On the other hand, Wampum was made of shell beads and was thus more durable, than cigarettes or stored tobacco. Tobacco warehouse receipts held their value, served as a medium of exchange and met the unit of account trait necessary to be money (Gentle, 2018). Therefore, one would probably wonder about gold and silver. How well do they retain value? Compare gold and silver to cocoa and the other items considered in Gentle (2016), Gentle, et al (2017) and Gentle (2018, 2020, 2021a, 2021b). Gold and silver have held their value quite well (Abdullah, 2013; Hart, 2013). Although very select paintings hold their value, as a general rule, artwork is not a comparatively good investment, in monetary terms. It may have some intangible values, such as the utility, "psychic income" in owning a work of art (Ekelund et al, 2017). Over time, the type of money that may best hold its value, in many situations could be based upon gold and silver (Greenspan, 1966; Abdullah, 2013). Indeed, both gold and silver have been used for a time, as an important basis for money (Gold, 2018). A detailed explanation of this goes beyond the scope of this article. In order for cocoa to have functioned as an early form of money, anytime, anywhere, it would have to have some perceived value.

\section{V.Summary and Conclusion}

When conventional forms of money are not ubiquitous at all, people may turn to substitutes, such as wampum or tobacco in the form of cigarettes or with a receipt in a warehouse or beaver fur pelts, or rice or other items. In this article, there has been a focus on the use of cocoa, as a form of money in certain historic times in some different parts of the World. In these cases, cocoa fulfilled the three requirements for something to be money. These are as unit of account, store of value and medium of exchange. Also any type of money can be used to pay debts. As the economic history of a place progresses, one can expect the forms of money to sometimes change. ${ }^{1}$

Endnote (1) Examining the Rai described in (Gentle, 2021b) research work been done by economist and anthropologists. Herskovits (1965) and Baron (2018), views economists as primarily concerned with material welfare, while anthropologists care about relationships. The fact is economists care about material welfare and relationships. The service sector of an economy is very much about relationships. Also, economists sometimes use a non-pecuniary approach. Economics is a social science and as with some other social sciences, takes into consideration an unlimited number of factors in explaining human behavior, including how this relates to institutions, such as government, firms, and others. As with all social sciences, both economics and 
anthropology can simultaneously add to many discussions of social science topics. (Gentle, 2016; Gentle and Giliberti, 2017; Gentle, 2018, Gentle, 2021a, 2021b ). In Gentle and Giliberti (2017) the reality of art works during the Nazi era being used to hold value was examined. Though the art certainly had a store of value, it could not be broken down into units of accent, nor was it the medium of exchange for the general society. Therefore, art during the Nazi era failed to meet all three criteria necessary for something to be considered money in the economic sense (Gentle, 2017). Wampum was sometimes made by Native Americans and sometimes by Western settler in colonial times (Myers, 1970; Pena, 2001, 2003; Gentle, 2016). Another form of early money used in Mesoamerica was the quachtli was a standardized cotton cloth used as commodity money in Post-Classic Mesoamerica, most notably within the Aztec tributary empire. Importantly, this quachtli could be converted into cocoa. Cocoa was the most dominant early form of money (Beanz, 2011; Nahuatl, 2020).

Funding: self-funded.

Author contribution: conceptualization, Paul F. Gentle; data curation, Paul F. Gentle; formal analysis, Paul F. Gentle; funding acquisition, Paul F. Gentle; investigation, Paul F. Gentle; methodology, Paul F. Gentle; project administration, Paul F. Gentle; resources, Paul F. Gentle; software, Paul F. Gentle; supervision, Paul F. Gentle; validation, Paul F. Gentle; visualization, Paul F. Gentle; writing - original draft, Paul F. Gentle; writing review \& editing, Paul F. Gentle.

\section{References}

1. Abdullah, Adam (2013). Examining the Value of Money in America over the Long Term (1792-2009). International Journal of Economics and Finance, 5, November 10. Pp. 58-84. [Link].

2. Aguilar-Moreno, Manuel (2006). The Good and Evil of Chocolate in Colonial Mexico. In Mcneil, Cameron L. Chocolate in Mesoamerica: A Cultural History of Cacao, Gainesville: University Press of Florida, pp. 273-288. [Link].

3. Baron, Joanne P. (2018). Financialization: Making money in Mesoamerica. Currency production and procurement in the Classic Maya Financial system. Economic Antropology, 5, pp. 210-223. [Link].

4. Beanz, (2011). Beanz meanz mney. Mexicolore, August 23. [Link].

5. Brock, L. V. (1975). The Currency of the American Colonies: 1700 -1764: A Study in Colonial Finance and Imperial Relations, New York: Arno Press. [Link].

6. Carrasco, David (2008). Daily Life of the Aztecs. $2^{\text {nd }}$ ed., Indianapolis, IN, USA: Hackett Publishing Company. [Link].

7. Cocoa Money (2011). Encyclopedia of Money - cocoacurrency. [Link].

8. Ekelund, Robert B., Jr., John D. Jackson, Robert D. Tollison (2017). The Economics of American Art: Issues, Artists and Market Institutions, Oxford University Press. [Link].

9. Fowler, William R. (2006). In Mcneil, Cameron L. Cocoa Production, Tribute, and Wealth in SixteenthCentury Izalcos, El Salvador. Chocolate in Mesoamerica: A Cultural History of Cacao, Gainesville: University Press of Florida, pp. 307-321. [Link].

10. Gentle, Paul F. (2016). Native American Wampum for Non-Monetary Uses and For Use as Money, Public and Municipal Finance, 3, pp. 16-21. [Link].

11. Gentle, Paul F. And Marco Giliberti, (2017). Were Valuable Art Works an Economic form of Money during the Third Reich period in Germany? Public and Municipal Finance, pp. 33-38. [Link].

12. Gentle, Paul F. (2018). Were Warehouse Receipts for Tobacco an economic form of money during the Colonial period in Virginia. Public and Municipal Finance, 7(1), 37-42. [Link].

13. Gentle, Paul F. (2020). Beaver pelts as Early forms of Money in the Economic Sense: Satisfying Store of Value, Unit of Account and Medium of Exchange Requirements, Strategies in Accounting and Management. [Link].

14. Gentle, Paul F. (2021a). Rice as an Early form of Money in the Economic Sense: Satisfying Store of Value, Unit of Account and Medium of Exchange Requirements. Socioeconomic Challenges, 5(1), pp. 5156. [Link]. 
15. Gentle, Paul F. (2021b). Stone Money of Yap as an Early Form of Money in the Economic Sense. Financial Markets; Institutions and Risks, 5(2), 114-119. [Link].

16. Gittings, Tom and Ken Goldsmith (2006). Money Matters: The American Experience with Money, Federal Reserve Bank of Chicago, Illinois.

17. Gold (2018). World Gold Council "Money and Gold," July 9. [Link].

18. Greenspan, A. (1966). Gold and economic freedom. The Objectivist Newsletter. [Link].

19. Hart, Matthew (2013). The Race for the World's Most Seductive Metal, Simon and Schuster. [Link].

20. Henderson, John S. And Rosemary A. Joyce (2006), "Brewing Distinction: The Development of Cocoa Beverages in Formative Mesoamerica," pp. 140-153. [Link].

21. Hersokovits, Melville J. (1965). Economic Anthropology: The Economic Life of Primitive Peoples. New York: W.W. Norton, Incorporated. [Link].

22. Horizon (2001). Money in the Fur Trade. Horizon Canada (English Edition), N. PAG. CA: De Marque, Inc. [Link].

23. Kaufman, Terrence and John Justerson (2006). The History of the Word for 'Cocoa' and Related Terms in Ancient Meso-America. In Mcneil, Cameron L. Chocolate in Mesoamerica: A Cultural History of Cacao, Gainesville: University Press of Florida, pp.117-139. [Link].

24. Leduc, Adtieene (2000). Old Money, Beaver, pp. 8-12. [Link].

25. Learn, Joushua Rapp (2018). The Maya civilization used chocolate as money. June 27. [Link].

26. Mankiw, N. Gregory (2015). Principles of Economics. Stamford, CT: Cenage Publishers. [Link].

27. Mcanany, Patricia A. and Satura Murata (2006). Belizean Caco Farmers Through the Ages, in Mcneil, Cameron L., Chocolate in Mesoamerica: A Cultural History of Cacao, Gainesville: University Press of Florida, pp. 429-450. [Link].

28. Mcneil, Cameron L. (2006). Introduction. In Mcneil, Cameron L. Chocolate in Mesoamerica: A Cultural History of Cacao, Gainesville: University Press of Florida, pp. 1-28. [Link].

29. Menger, Carl (1871). Principles of Economics, original title: Grundsätze der Volkswirtschaftslehre Auburn, AL, USA: Ludwig von Mises Institute. [Link].

30. Millon, Rene' F. (1955). When Money grew on Tress: A Study of Cocoa in Ancient Mesoamerica, Ph.D. Dissertation, Columbia University. [Link].

31. Mishkin, Frederic S. (2006). The Economics of Money, Banking, and Financial Markets, New York: Pearson Addison-Wesley. [Link].

32. Myers, Margret. (1970). A Financial History of the United States. New York: Columbia University. [Link].

33. Nahuatl (2020). "Quachtli". Nahuati Dictionary, National Endowment for the Humanities. [Link].

34. Nettles, Augustus M. (1964). The Money Supply of the American Colonies before 1720, New York: Sentry Press. (Reprint of 1934 edition). [Link].

35. Nield, David (2018). New Study Reveals the Ancient Maya used their most famous Crop as Actual Money. Science Alert, June 29. [Link].

36. Palace, Steve (2018). Strange but True: Ancient Mayans used Chocolate as Money, July 9. [Link].

37. Pearce, David W. (1986). Macmillan Dictionary of Modern Economics. New York: Macmillan Publishing Company. [Google Scholar].

38. Peña, Elizabeth S. (2001). The role of wampum production at the Albany almshouse. International Journal of Historical Archaeology 5.2 (2001): 155-174. [Link].

39. Peña, Elizabeth. (2003). Making "Money" the Old-Fashioned Way: Eighteenth-Century Wampum Production in Albany. People, Places, and Material Things: Historical Archaeology of Albany, New York (2003), 121-127. [Link].

40. Pugh, Timothy W. (2006). Cocoa, Gender, and the Northern Lacandon God House. In Mcneil, Cameron L., Chocolate in Mesoamerica: A Cultural History of Cacao, Gainesville: University Press of Florida, pp.367383. [Google Scholar].

41. Radford, R.A. (1945). The Economic Organization of a P.O.W. Camp. Economica, 12, 48, pp. 189-201. [Google Scholar]. 
42. Reents-Budet, Dorie (2006). The Social Context of Kakaw Drinking among the Ancient Maya. In Mcneil, Cameron L. Chocolate in Mesoamerica: A Cultural History of Cacao, Gainesville: University Press of Florida. 202-203. [Link].

43. Rothbard, Murray N. (2002). A History of Money and Banking in the United States: The Colonial Era to World War II, Auburn, Alabama: Ludwig Von Mises Institute. [Link].

44. Steinbrenner, Larry (2006). Cacoa in Greater Nicoya: Ethnohistory and a Unique Tradition. In Mcneil, Cameron L. Chocolate in Mesoamerica: A Cultural History of Cacao, Gainesville: University Press of Florida, pp.202-223. Pp. 253-270. [Link].

45. Stigler, George (1950). The Development of Utility Theory. The Journal of Political Economy, 58, 4, pp. 307-327. [Link]. 